\title{
Drying temperature changes trichome integrity, chemical content and composition of the essential oil of pepper-rosmarin
}

\author{
Giovanna Alcântara Queiroz ${ }^{1^{*}} \odot$ Pedro Henrique Lopes Silva ${ }^{1}$

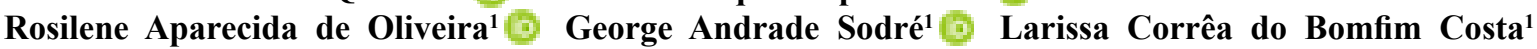

\begin{abstract}
${ }^{1}$ Universidade Estadual de Santa Cruz (UESC), Av. Ilhéus-Itabuna, Km 16, Salobrinho, 46650-000, Ilhéus, BA, Brasil. E-mail: joalqme@hotmail.com. *Corresponding author.

ABSTRACT: Medicinal plants are generally commercialized dried. However, temperatures used in their drying processes may interfere with the content and chemical composition of their essential oils. The Lippia origanoides possesses thymol in the essential oil that is stored in glandular trichomes. Thymol is a major component of economic importance in the chemical and pharmaceutical industry. The objective of this study was to evaluate the effect of the drying temperatures of L. origanoides leaves regarding trichome integrity, content, and chemical composition of the essential oil. The experimental design was completely randomized with four treatments defined by oven drying temperatures $\left(40,50,60\right.$, and $\left.70^{\circ} \mathrm{C}\right)$ and four replications. Essential oil was extracted by hydro distillation and the essential oil contents were determined (\%). Chemical composition of the oil was analyzed by gas chromatography coupled to mass spectrometry. Scanning electron microscopy was carried out to determine trichome integrity. Drying the L. origanoides leaves in a forced ventilation oven at $40^{\circ} \mathrm{C}$ minimized the loss of extracted essential oil content $\left(17.5 \mathrm{~g} \mathrm{~kg}^{-1}\right)$ and relative thymol percentage. Leaves dried at the temperatures of 60 and $70^{\circ} \mathrm{C}$ exhibited a higher percentage of ruptured trichomes and reduced essential oil content to $13.7 \mathrm{~g} \mathrm{~kg}^{-1}$ and $11.8 \mathrm{~g} \mathrm{~kg}^{-1}$, respectively.
\end{abstract}

Key words: Lippia origanoides, medicinal plant, secretory structures, drying, thymol.

Temperatura de secagem altera integridade de tricomas, teor e composição química do óleo essencial de alecrim-pimenta

RESUMO: As plantas medicinais são geralmente comercializadas secas, no entanto, as temperaturas utilizadas nos processos de secagem podem interferir no teor e composição química dos óleos essenciais destas plantas. A Lippia origanoides possui timol em seu óleo essencial, que se encontra armazenado em tricomas glandulares. O timol é um componente majoritário de importância econômica na indústria química e farmacêutica. O objetivo do trabalho foi estudar o efeito das temperaturas de secagem de folhas de L. origanoides na integridade dos tricomas, teor e composição química do óleo essencial. O delineamento experimental foi inteiramente casualizado, com quatro tratamentos definidos por temperaturas de secagem em estufa $\left(40^{\circ} \mathrm{C}, 50^{\circ} \mathrm{C}, 60^{\circ} \mathrm{C}\right.$ e $\left.70^{\circ} \mathrm{C}\right)$ e quatro repetições. Foram realizadas extrações por hidrodestilação e determinação dos teores dos óleos essenciais (\%), análise de composição química do óleo por cromatografia gasosa acoplada à espectrometria de massas e microscopia eletrônica de varredura para determinação da integridade dos tricomas. A secagem das folhas de L. origanoides em estufa de ventilação forçada a $40^{\circ} \mathrm{C}$ minimizou a perda do teor de óleo essencial extraído $\left(17,5 \mathrm{~g} \mathrm{~kg}^{-1}\right)$ e porcentagem relativa de timol. Folhas secas em temperatura de 60 e $70^{\circ} \mathrm{C}$ exibiram maior porcentagem de tricomas rompidos e redução do teor de óleo essencial para $13,7 \mathrm{~g} \mathrm{~kg}^{-1}$ e $11,8 \mathrm{~g} \mathrm{~kg}^{-1}$, respectivamente.

Palavras-chave: Lippia origanoides, planta medicinal, estruturas secretoras, secagem, timol.

\section{INTRODUCTION}

The drying process in medicinal plants interferes with the quantity and quality of the vegetal material used to extract essential oil and reduces the water content in the plant and consequently the enzymatic action of microorganisms. This inhibits hydrolysis, oxidation and fermentation, facilitates storage, and reduces transport costs (COSTA et al., 2005; ROCHA et al., 2012; CORRÊA JUNIOR \& SCHEFFER, 2013). In this context, the moisture content of plant material within pharmacopoeia quality standards should range from 8 to $12 \%$ (FARMACOPÉIA BRASILEIRA, 2010).

Drying temperatures for medicinal plants vary and depend fundamentally on 
the species, plant tissue, and environmental conditions. Therefore, studies have shown that the appropriate temperature is the one that maintains the highest content of essential oil without significantly changing the chemical composition. Influence of the drying processes on the quality and quantity of essential oil was verified in species of the genus Lippia (BARBOSA et al., 2006). This influence has also been reported in other medicinal species such as basil (Ocimum basilicum L.), guaco (Mikania glomerata Sprengel), thyme (Thymus vulgaris L.), Achillea frayrantissma L., and Artemisia herb-alba Asso (SOARES et al., 2007; RADÜNZ et al., 2010; ROCHA et al., 2012; ABAAS et al., 2013). In Ocimum gratissimum L., the authors observed changes in the secretory structure responsible for oil production and storage (SANTANA et al., 2014).

Lippia origanoides is a medicinal species of the Brazilian flora (SALIMENA \& MÚRGURA, 2015), popularly known as rosemary-pepper and orégano-do-monte (OLIVEIRA et al., 2007). Its essential oil is rich in thymol and carvacrol, which are important substances for the chemical and pharmaceutical industry due to their antimicrobial properties used in dental creams, oral antiseptics, decongestant ointments, and tablets such as Euthymol ${ }^{\circledR}$, Listerine $^{\circledR}$, Vick Vaporub ${ }^{\circledR}$, and Valda ${ }^{\circledR}$. In popular medicine, L. origanoides is used for treating stomach pain, indigestion, diarrhea, respiratory problems, and as a general antiseptic for the mouth, throat, and wounds (PASCUAL et al., 2001). In addition, it presents fungicidal, bactericidal, and repellent action (NERIO et al., 2009; OSPINA et al., 2011; ALMEIDA et al., 2016). The essential oil of $L$. origanoides is reported in the glandular trichomes, which are external and sensitive structures, significantly present on the surface of leaves and flowers (TOZIN et al., 2015). This fact may cause changes in the content and chemical composition of the material, as verified for Melissa officinalis and Ocimum gratissimum (ARGYROPOULOS \& MÜLLER, 2014; SANTANA et al., 2014).

Although, the species L. origanoides has been studied for its chemical composition (VICUÑA et al., 2010), little is known about how drying temperatures affect the quality of the raw material to be commercialized. Therefore, the objective of this study was to evaluate the effect that different drying temperatures have on L. origanoides leaves regarding the integrity of glandular trichomes, content, and chemical composition of the essential oil.

\section{MATERIALS AND METHODS}

The experimental design was completely randomized, with four treatments, which were defined by forced-circulation air-drying temperatures $(40,50$, 60 , and $70^{\circ} \mathrm{C}$ ) and four replications.

\section{Plant material}

The experiment was conducted at Universidade Estadual de Santa Cruz (UESC) in Ilhéus, Bahia, in October 2016. Samples were obtained from 2-year-old mother plants grown at the UESC Medicinal Plant Garden. Herbarium specimens of the botanical material are kept in the UESC Herbarium under registration No. 21282. Leaves were collected from the middle portion of the mother plants between 9am and 9:30am, carefully labeled, and sent to the laboratory for analysis. Selection of the leaves was carried out regarding their integrity, free from insect or disease injury.

\section{Drying the material}

For the drying process, $1.6 \mathrm{~kg}$ of leaves was homogenized and separated by experimental unit (100g of fresh leaf), which totaled $400 \mathrm{~g}$ of leaves per treatment. The whole leaves were arranged in a $1.5 \mathrm{~cm}$ thick layer in forced circulation oven trays. Sample drying was completed when the material reached the final mass equivalent to the desired humidity $(10 \%$ b.u.), which was calculated according to the methodology by BARBOSA et al., (2006). Once dried, the samples were packed in kraft paper bags and stored in polyethylene bags for further extraction of the essential oil.

\section{Moisture determination}

To determine the initial moisture, $25 \mathrm{~g}$ samples of leaves were placed to dry immediately after collection in an oven at $105^{\circ} \mathrm{C}$ for 24 hours. This methodology was recommended by ASAE STANDARDS, (2000) for fodder and similar material. 


\section{Essential oil extraction and analysis}

Extraction of the essential oil was carried out by hydro distillation in a Clevenger apparatus at the time of extraction, which was determined by the authors according to the curve of the extraction time previously performed (150 minutes). The oil was separated from the hydrolate with dichloromethane $(3 \times 10 \mathrm{~mL})$, dried with anhydrous sodium sulfate, and concentrated until complete evaporation of solvent. The oil content was expressed as $\mathrm{g} \mathrm{kg}^{-1}$ dry matter. The obtained oil mass was determined by analytical weighing.

Quantitative chemical composition was evaluated by gas chromatography coupled to the flame ionization detector (GC-FID) using a Varian Saturm 3800 gas chromatograph equipped with VF5-ms fused silica capillary column (30m X $0.25 \mathrm{~mm}$ ) with stationary phase $5 \%$ phenyl-95\% dimethylpolysiloxane $(0.25 \mu \mathrm{m}$ film thickness $)$, with helium 6.0 as entrainment gas and flow of $1.2 \mathrm{~mL}$. $\min ^{-1}(10 \mathrm{psi})$. The injector and detector temperatures were 250 and $280^{\circ} \mathrm{C}$, respectively. Afterwards, $1.0 \mu \mathrm{L}$ of solution in $\mathrm{CHCl}_{3}$ at $10 \%$ in split mode $(1: 10)$ was injected. Temperature of the column started at $60^{\circ} \mathrm{C}$, increasing $8^{\circ} \mathrm{C}$ per minute until reaching and maintaining $240^{\circ} \mathrm{C}$ for 5 minutes. This procedure took 27.5 minutes. Component quantification was obtained by electronic integration of the peaks detected in the FID by standardization. Qualitative analysis was performed on a Varian Saturn 2000 mass spectrometer. Column and temperature conditions were the same as in the CG-FID analysis, with the temperature of the transferline set at $250^{\circ} \mathrm{C}$, manifold at $50^{\circ} \mathrm{C}$, and trap at $150^{\circ} \mathrm{C}$. Operation mode was the electrical impact of $70 \mathrm{eV}$ at a scan rate of $1 /$ second (s) within a range of 40 to $450 \mathrm{Da}$ at a sampling rate of $1.2 \mathrm{scan} / \mathrm{s}$. Oil components were identified by analyzing the fragmentation patterns observed in the mass spectra and confirmed by comparing results from mass spectra with those present in the database provided by the equipment (NIST, 2017). Oil components were also identified by comparing their retention indices with the known compounds obtained by injecting a mixture of standards containing a homologous series of alkanes $\mathrm{C}_{8}-\mathrm{C}_{26}$ (sigma - USA), and reference data of the literature (ADAMS, 2012).

Relative content of the major compound (thymol) was calculated in relation to the essential oil content of each drying temperature by the formula: (Treatment oil content $(\%)$ x percentage of compound*)/100.

${ }^{*}$ Considering the standardization provided by CG-FID analysis.

\section{Micromorphological analysis}

Micromorphological analysis of the leaf surface was performed at the Center of Electron Microscopy (CEM) of UESC. Samples of the medium portion of fully expanded dry leaves were fixed in a metal holder covered with carbon tape and metallized with gold (BAL-TEC SCD 050) for observation and recording on the Scanning Electron Microscope (QUANTA 250, FEI COMPANY). Five replicates (images) of the abaxial face of the leaves were selected with magnification of 300 to determine the percentage of ruptured, deflated, and intact glandular trichomes (methodology adapted from SANTANA et al., 2014).

\section{Statistical analysis}

Content data and relative content of thymol were submitted to analysis of variance, and the quantitative values of drying temperatures were submitted to regression analysis with linear and quadratic coefficients using the statistical program Sisvar (FERREIRA, 2011). Models that presented all significant coefficients up to $5 \%$ by the $\mathrm{F}$ test and the highest adjusted coefficient of determination were accepted. Correlations were obtained between the mean values of glandular trichomes and drying temperatures.

\section{RESULTS AND DISCUSSION}

The maximum drying periods for $L$. originoides leaves to reach constant mass were 380 minutes at $40^{\circ} \mathrm{C}$, followed by 195,140 , and 100 minutes at temperatures of 50,60 and $70^{\circ} \mathrm{C}$, respectively. There was an average reduction of $70 \%$ from fresh mass to dry mass. Increasing the drying temperature reduced linearly the essential oil content ( $\mathrm{p}<0.01)$, with the temperatures of 50 , 60 , and $70^{\circ} \mathrm{C}$ reducing the oil content by $12.1,23.0$, and $34.5 \%$ in relation to drying at $40^{\circ} \mathrm{C}(17.5 \mathrm{~g}$ $\mathrm{kg}^{-1}$ ) (Figure 1). This reduction may be attributed to alterations of the pelleted glandular trichomes located in the abaxial epidermis of the leaves (Figure 2). Percentage of ruptured trichomes was proportional to the increases in temperature. This 


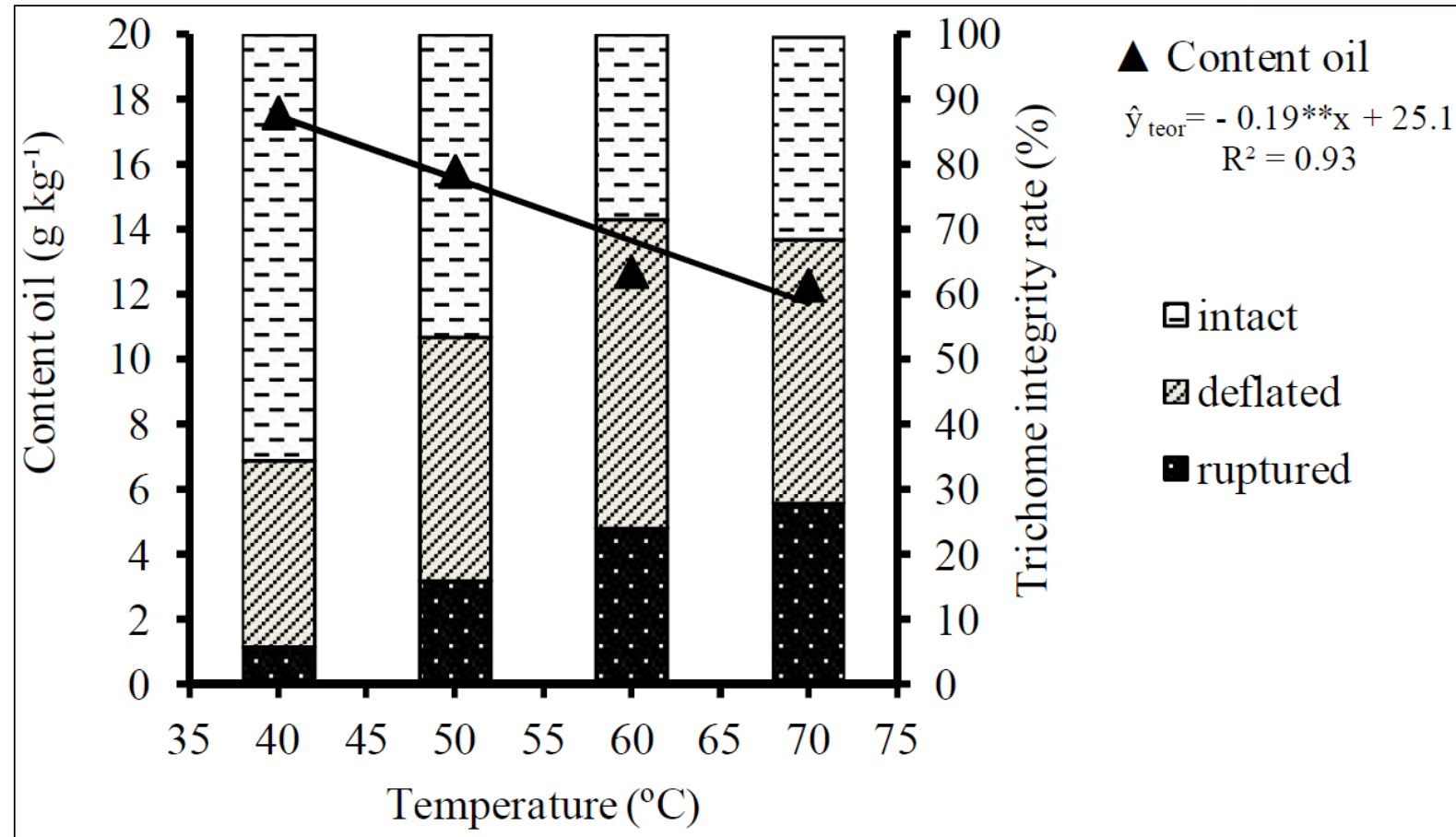

Figure 1 - Essential oil content and leaf trichome integrity rate of Lippia origanoides due to drying temperatures. Ilhéus - BA, 2016. CV = 11.3\%.

rupture occurred generally at the base or apex of the head of trichomes (Figure 2A).

A positive and significant correlation $(p<0.01)$ was observed between the drying temperatures and amount of ruptured and deflated trichomes (Figure 3A and 3B), whereas a negative correlation was observed between drying temperatures and intact trichomes (Figure 3C). Drying leaves at temperatures above $40^{\circ} \mathrm{C}$ caused greater trichome rupture and increased oil volatilization.

Sensitivity of the chemical compounds of the oil in addition to the structural changes in the glandular trichomes caused by drying temperature may have induced oil loss (ARGYROPOULOS \& MÜLLER, 2014; SANTANA et al., 2014). The Melissa officinalis
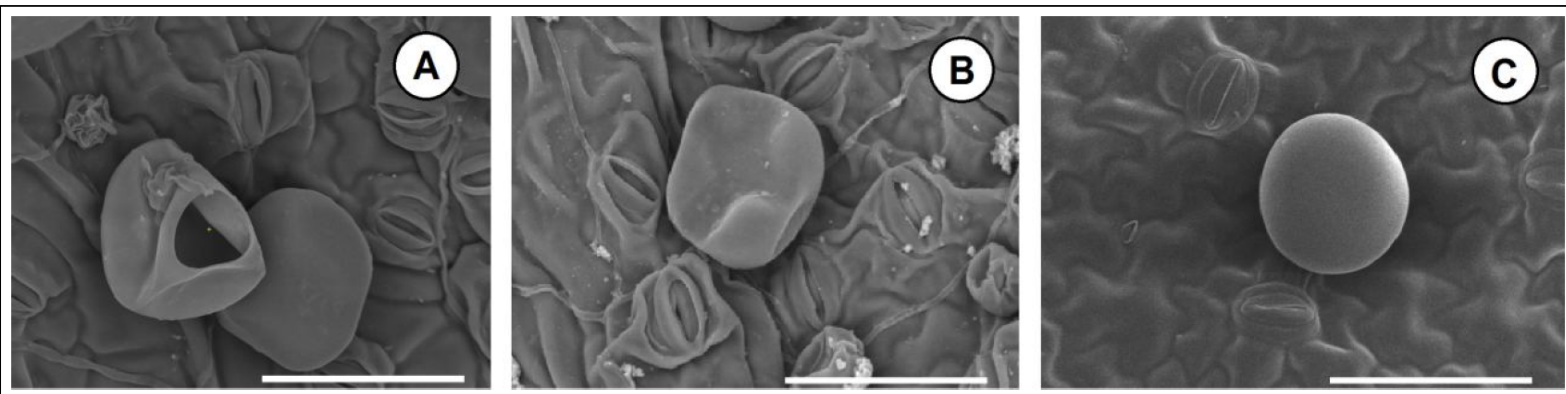

Figure 2 - Scanning electron microscopy of glandular trichomes of Lippia origanoides leaves submitted to drying temperatures $\left(40^{\circ} \mathrm{C}\right.$, 50 ${ }^{\circ} \mathrm{C}, 60{ }^{\circ} \mathrm{C}$, and $\left.70^{\circ} \mathrm{C}\right)$ : ruptured (A); deflated (B); intact $(\mathrm{C})$. Bar $=50 \mu \mathrm{m}$. 

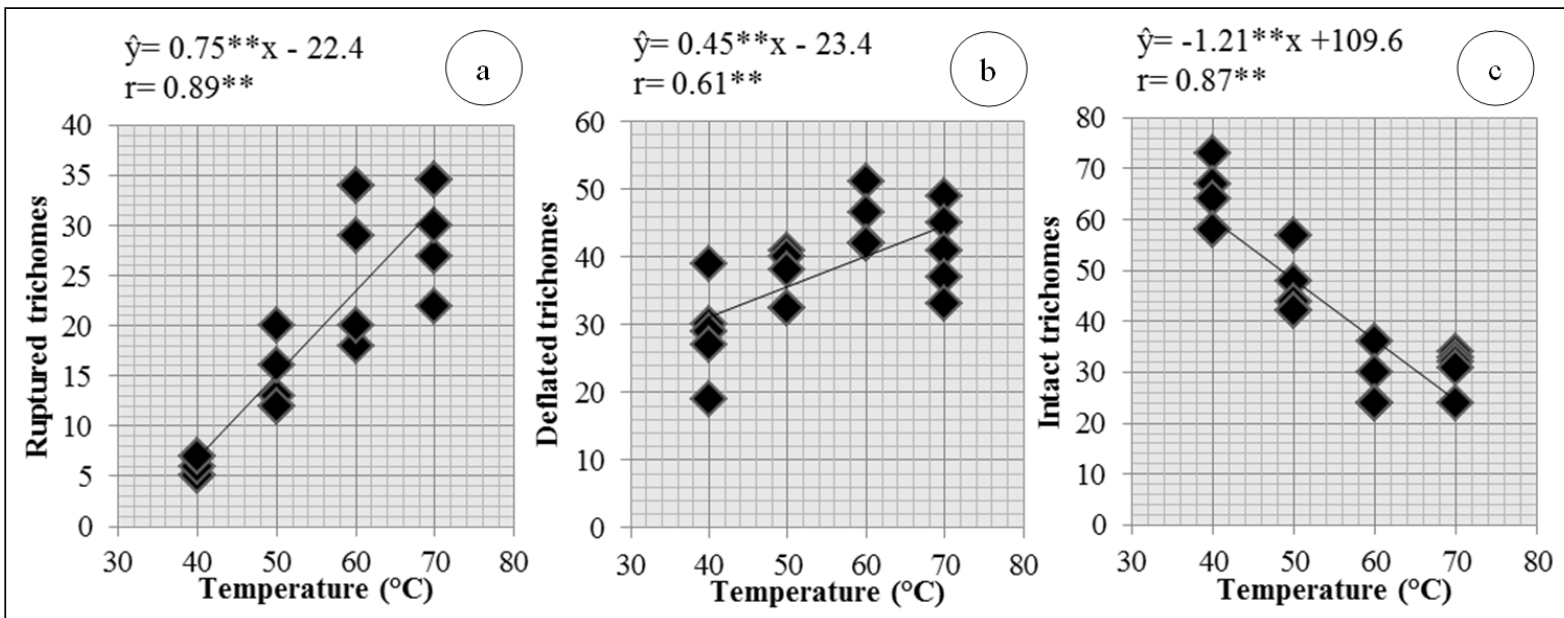

Figure 3 - Linear correlations between the drying temperature and integrity of glandular trichomes: ruptured (A); deflated (B); intact (C) in Lippia origanoides leaves.

L. and Ocimum gratissimum also had significant reduction in oil content influenced by the rupture of the secretory trichomes and volatilization of the chemical components when submitted to drying temperatures (ARGYROPOULOS \& MÜLLER, 2014; SANTANA et al., 2014). SANTANA et al. (2014) verified the fragility of trichomes in medicinal plants and recommended attention to harvesting and processing and drying processes, especially when these structures are present on the leaf surface. For basil (Ocimum basilicum L.), it is suggested to dry the leaves at $40^{\circ} \mathrm{C}$ (SOARES et al., 2007), whereas for Achillea frayrantissma and Artemisia herb-alba, drying should be done at $35^{\circ} \mathrm{C}$ (ABAAS et al., 2013).

For other species of the genus Lippia, the drying temperature of leaves does not interfere with oil content. Furthermore, Lippia alba showed that, even in the drying process with temperatures between 30 and $70^{\circ} \mathrm{C}$, there was no significant difference in the content of extracted essential oil. Contrastingly, when comparing dried Lippia alba to the fresh planta reduction of 12 to $17 \%$ in extraction of essential oil content was observed (BARBOSA et al., 2006). These authors reported that there was no drying effect because the oil in $L$. alba is stored not only in structures of leaf epidermis (secretory trichomes), but also in palisade and lacunal parenchyma cells (BARBOSA et al., 2006).
In species such as lemongrass (Cymbopogon citrates (DC) Stapf.) and guaco (Mikania glomerata Sprengel), drying temperature of $50^{\circ} \mathrm{C}$ provided a significant increase in the extracted oil content when compared to drying at $40^{\circ} \mathrm{C}$. These results were attributed to the location of the oil storage structures (secretory pockets or channels) present in the tissues of the leaf parenchyma. Therefore, these structures are less susceptible to the effects of drying temperature when compared to external structures, such as glandular trichomes (BUGGLE et al., 1999; RADÜNZ et al., 2010).

Results of this study indicated that the species $L$. origanoides presents different responses on the extracted oil content as a function of leaf drying temperature. This difference in plant material sensitivity to drying temperature among species can be attributed to secretory structures and their location in plants, as well as to chemical composition of the essential oil (ARGYROPOULOS \& MÜLLER, 2014).

In the essential oil of $L$. origanoides, ten chemical compounds were identified (Table 1). These compounds were grouped into phenylpropanoids, major compounds (2.64-71.52\%), sesquiterpenes (5.40-6.38\%), monoterpenes (0.17-4.04\%), oxygenated monoterpenes (0.34-0.82\%), and oxygenated sesquiterpenes (0.97-1.29\%). Relative 
Table 1 - Chemical composition of the essential oil of Lippia origanoides leaves submitted to four drying temperatures. Ilhéus - BA, 2016.

\begin{tabular}{|c|c|c|c|c|c|c|c|}
\hline \multirow[t]{2}{*}{ Compounds } & \multirow[t]{2}{*}{$\mathrm{RI}^{\mathrm{a}}$} & \multirow[t]{2}{*}{ RI lit. $^{\mathrm{b}}$} & \multicolumn{4}{|c|}{-----------------Composition $(\%)^{\mathrm{c}}$----------------- } & \multirow[b]{2}{*}{ Class } \\
\hline & & & $40^{\circ} \mathrm{C}$ & $50^{\circ} \mathrm{C}$ & $60^{\circ} \mathrm{C}$ & $70^{\circ} \mathrm{C}$ & \\
\hline$\beta$-pinene & 989 & 980 & 0.17 & 0.97 & 0.77 & 0.18 & MH \\
\hline para-cymene & 1032 & 1026 & 4.67 & 8.33 & 7.32 & 5.20 & $\mathrm{PH}$ \\
\hline$\gamma$ - terpinene & 1065 & 1062 & 2.03 & 4.04 & 3.54 & 2.74 & MH \\
\hline Artemis yl-acetate & 1177 & 1173 & 0.62 & - & 0.52 & 0.34 & MO \\
\hline terpin-4-ol & 1189 & 1174 & 0.82 & 0.64 & 0.82 & 0.70 & MO \\
\hline para-cimen-7-ol & 1279 & 1287 & 9.19 & 8.49 & 8.72 & 9.53 & $\mathrm{PH}$ \\
\hline thymol & 1288 & 1290 & 71.52 & 65.81 & 67.24 & 69.20 & $\mathrm{PH}$ \\
\hline caryophyllene & 1428 & 1418 & 5.40 & 5.68 & 5.43 & 6.38 & $\mathrm{SH}$ \\
\hline terc-butyl-4-metoxiphenol & 1484 & 1488 & 2.96 & 2.91 & 2.54 & 2.66 & $\mathrm{PH}$ \\
\hline caryophyllene oxide & 1593 & 1581 & 1.14 & 1.29 & 1.17 & 0.97 & $\mathrm{SO}$ \\
\hline \multicolumn{8}{|l|}{ Compounds class } \\
\hline Phenylpropanoids (PH) & & & 88.34 & 85.54 & 85.82 & 86.59 & \\
\hline Sesquiterpenes hydrocarbons (SH) & & & 5.40 & 5,68 & 5.43 & 6.38 & \\
\hline Monoterpenes hydrocarbons (MH) & & & 2.20 & 5.01 & 4.31 & 2.92 & \\
\hline Oxygenated monoterpenes (MO) & & & 1.44 & 0.64 & 1.34 & 1.04 & \\
\hline Oxygenated sesquiterpenes (SO) & & & 1.14 & 1.29 & 1.17 & 0.97 & \\
\hline Total identified (\%) & & & 98.52 & 98.16 & 98.07 & 97.90 & \\
\hline
\end{tabular}

${ }^{a} \mathrm{RI}$ : experimental relative retention index: $\mathrm{C}_{8}-\mathrm{C}_{26}$ n-alkanes were used as points in the calculation of the relative retention index. ${ }^{\mathbf{b}} \mathrm{RI}$ lit: index of relative retention of the literature (ADAMS, 2012). ${ }^{\mathrm{c}}$ Values obtained through the standardization of areas.

thymol content is presented as a function of the drying temperatures $(p<0.01)$ in figure 4 . Thymol was extracted in larger quantities in leaves when the temperature of $40^{\circ} \mathrm{C}(1.26 \%)$ was used, while at $70^{\circ} \mathrm{C}$ there was significant reduction of the relative content (Figure 4). In this case, significant losses of the thymol component can be noted, which in practical terms, would mean great economic losses in industrial processing.

In general, convective drying (using hot air) leads to significant volatility loss, with losses proportional to increases in air temperature (DÍAZMAROTO et al., 2004; FIGIEL et al., 2010). As for oil quality, SUNTHONVIT et al. (2005) reported that not only drying temperatures interfere with the extracted oil content, but they also recommend observing the synthesis or degradation of volatile compounds related to this temperature and at which temperature the major component of economic interest is present in higher concentrations.
Studies have shown that medicinal plants exhibit changes in the chemical composition of the essential oil as a result of increasing drying temperatures, such as in the case of clove basil (Ocimum gratissimum L.) (SANTANA et al., 2014), Melissa officinalis (ARGYROPOULOS \& MÜLLER, 2014), and guaco (Mikania glomerata Sprengel) (RADÜNZ et al., 2010). However, this does not occured for all components, as observed by ROCHA et al., (2012), who worked with drying Thyme (Thymus vulgaris L.) in which there was no significant difference for thymol, para-cymene, and trans-caryophyllene compounds.

\section{CONCLUSION}

For the species L. origanoides, it is recommended to dry leaves at a temperature of $40^{\circ} \mathrm{C}$ in order for the trichomes to remain intact and enable higher content of essential oil and major compound (thymol) to be extracted. 


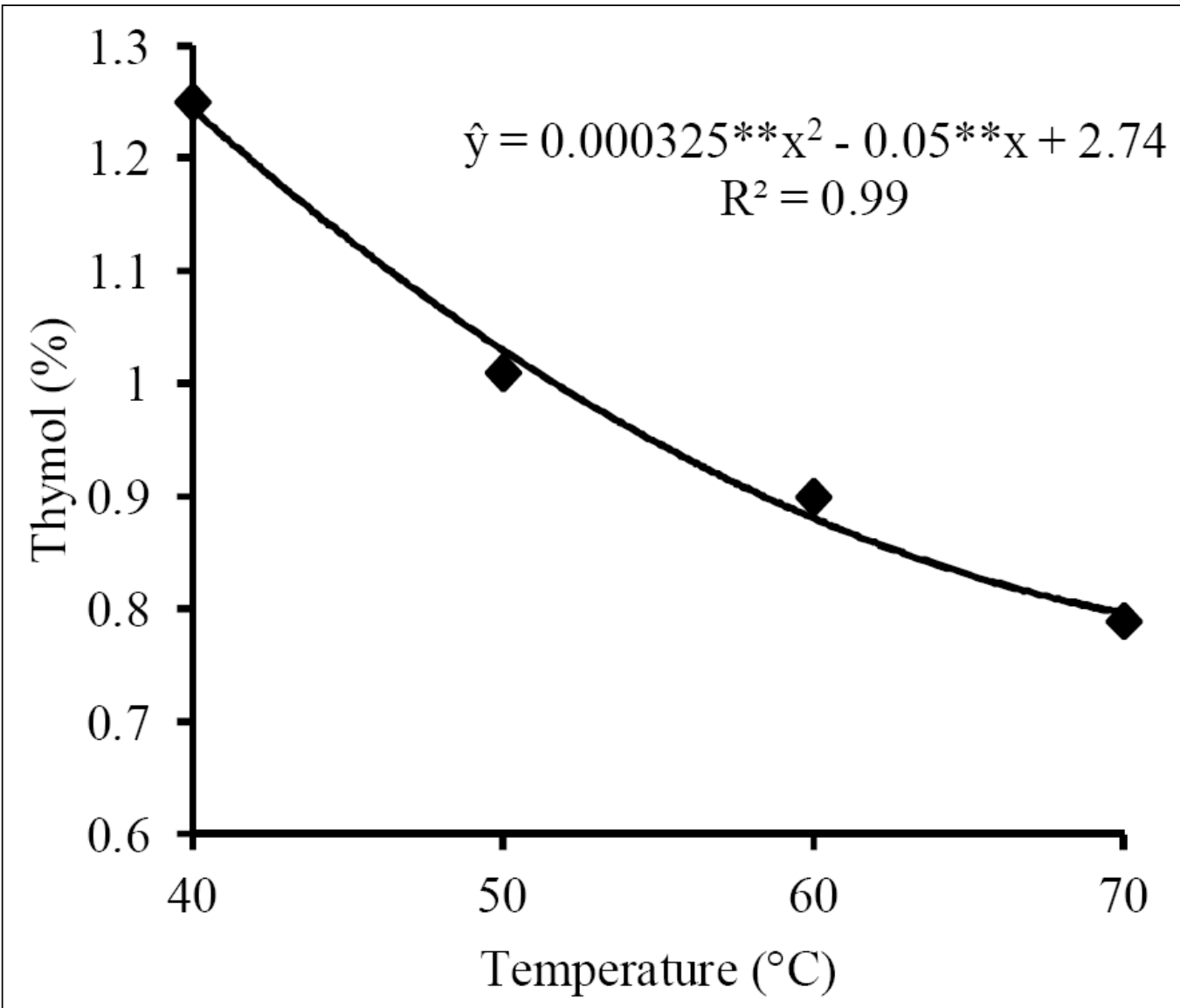

Figure 4 - Relative thymol content (\%) of dry L. origanoides leaves subjected to drying temperatures. Ilhéus - BA, 2016. ${ }^{* *}$ Significant at $1 \%$ probability. $\mathrm{CV}=1.3 \%$.

\section{ACKNOWLEDGMENTS}

The Coordenação de Aperfeiçoamento de Pessoal de Nível Superior (CAPES) for the financial support and the Center for Electronic Microscopy (CEM/UESC) and employees for collaborating in this study.

\section{DECLARATION OF CONFLICTING INTERESTS}

The authors declare no conflict of interest. The founding sponsors had no role in the design of the study; in the collection, analyses, or interpretation of data; in the writing of the manuscript, and in the decision to publish the results.

\section{AUTHORS' CONTRIBUTIONS}

All authors contributed equally for the conception and writing of the manuscript. All authors critically revised the manuscript and approved of the final version.

\section{REFERENCES}

ABAAS, I. S. et al. Analysis with evaluation of drying temperature on essential oil content of Achillea frayrantissima L. and Artemisia herb-alba L. International Journal of Pharmacy and Pharmaceutical Sciences, v.5, n.3, p.913-914, 2013.

ADAMS, R.P. 2012. Identification of essential oil Components by Gas chromatography/mass spectrometry, 4th Edn. Carol Stream, Illinois, $804 \mathrm{p}$.

ALMEIDA, A. C. et al. Antiseptic activity of Lippia origanoides essential oil (rosemary pepper) in the presence of bovine milk. Revista Pesquisa Veterinária Brasileira, v.36, n.9, p.905-911, 2016.

ARGYROPOULOS, D. et al. Changes of essential oil content and composition during convective drying of lemon balm (Melissa officinalis L.). Industrial Crops and Products, v.52, p.118-124, 2014. Available from: <https://www.sciencedirect.com/science/ article/pii/S0926669013005724>. Accessed: Oct. 3, 2018. doi: 10.1016/j.indcrop.2013.10.020.

Ciência Rural, v.48, n.11, 2018. 
ASAE STANDARDS. Standards engineering practices data: moisture measurement forages, ASAE S358.2 DEC99. Adopted and published by American Society of agricultural Engineers, 2000. p. $565-72$.

BARBOSA, F. F. et al. Influence of drying air temperature on the content and chemical composition of the essential oil of Lippia alba (Mill) N. E. Brown. Química Nova, v.29, n.6, p.1221-1225, 2006. Available from: <http://www.scielo.br/scielo.php?script=sci_artt ext\&pid=S0100-40422006000600014>. Accessed: Oct. 3, 2018. doi: 10.1590/S0100-40422006000600014.

BUGGLE, V. et al. Influence of different drying temperatures on the amount of essential oils and citral content in Cymbopogon citrates (DC) Stapf. Poaceae. Acta Horticulturae, v.500, n.500, p.7174, 1999. Available from: <http://hdl.handle.net/11449/65993>. Accessed: Oct. 3, 2018. doi: 10.17660/ActaHortic.1999.500.8.

CORRÊA JUNIOR, C.; SCHEFFER, M. C. Boas Práticas Agrícolas (BPA) de Plantas Medicinais, Aromáticas e Condimentares. Curitiba: Instituto Emater, 2013. 52 p.: il., (Série Informação Técnica, n. 88) ISBN: 978-85-63667-32-8.

COSTA, L.C.B. et al. Drying and fragmentation of the dry matter in the yield and composition of the essential oil of lemongrass. Horticultura Brasileira, v.23, n.4, p.956-959, 2005. Available from: <http://www. scielo.br/pdf/hb/v23n4/a19v23n4>. Accessed: Mar. 20, 2018.

DÍAZ-MAROTO, M.C. et al. Changes produced in the aroma compounds and structural integrity of basil (Ocimum basilicum L.) during drying. Journal of the Science of Food and Agriculture, v.84, n.15, p.2070-2076, 2004. Available from: <https:// onlinelibrary.wiley.com/doi/abs/10.1002/jsfa.1921>. Accessed: Mar. 20, 2018. doi: 10.1002/jsfa. 1921.

FARMACOPÉIA BRASILEIRA. 5 ed., v.1 e 2. Brasília: Agência Nacional de Vigilância Sanitária, 2010. 808p.

FERREIRA, D.F. Sisvar: A computer statistical analysis system. Ciência e Agrotecnologia, Lavras, v.35, n.6, p.1039-1042, 2011.

FIGIEL, A. et al. Composition of oregano essential oil (Origanum vulgare) as affected by drying method. Journal of Food Engineering, v.98, n.2, p.240-247, 2010.

NERIO, L.S. et al. Repellent activity of essential oils from seven aromatic plants grows in Colombia against Sitophilus zeamais Motschulsky (Coleoptera). Journal of Stored Products Research, v.45, n.3, p.212-214, 2009.

NIST (National Institute of Standards and Technology), 2017. Available from: <http://webbook.nist.gov/chemistry/name-ser. html>. Accessed: Apr. 18, 2018.
OLIVEIRA, D.R. et al. Chemical and antimicrobial analyses of essential oil of Lippia origanoides H.B.K. Food Chemistry, v.101, n.1, p.236-240, 2007.

OSPINA, D. et al. Evaluación in vitro de la actividad inhibitoria de aceites esenciales de Lippia origanoides H.B.K. sobre el desarrollo micelial y la formación de esclerocios de Sclerotium cepivorumBerk. Acta Agronómica, v.60, n.4, p.306-311, 2011.

PASCUAL, M. E. et al. Lippia: traditional uses, chemistry and pharmacology. A review. Journal of Ethnopharmacology, v.76, n.3, p.201-214, 2001.

RADÜNZ, L.L. et al. Study of essential oil from guaco leaves submited to different drying air temperature. Engenharia na Agricultura, v.18, n.3, p.241-247, 2010.

ROCHA, R. P.et al. Influence of the drying process on the main chemical components of the essential oil of thyme. Revista Ceres, v. 59, n.5, p. $731-737,2012$.

SALIMENA, F.R.G.; MÚLGURA, M. 2015. Lippia in Lista de Espécies da Flora do Brasil. Jardim Botânico do Rio de Janeiro. 2015. Available from: <http://floradobrasil.jbrj.gov.br/jabot/ floradobrasil/FB21449>. Accessed: Mar. 20, 2018.

SANTANA, A. C. M. et al. Rupture of glandular trichomes in Ocimum gratissimum leaves influences the content of essential oil during the drying method. Revista Brasileira de Farmacognosia, v.24, n.5, p.524-530, 2014. Available from: <http://www.scielo. br/scielo.php?script $=$ sci abstract\&pid $=S 0102-695 X 2014000500$ 524\&lng=pt\&nrm=iso $>$. Accessed: Oct. 03, 2018. doi: 10.1016/j. bjp.2014.10.006.

SOARES, R. D. et al. Influence of air temperature and velocity on basil (Ocimum basilicum L.) drying in relation to essential oil and linalool contents. Ciência e Agrotecnologia, v.31, n.4, p.1108-1113, 2007. Available from: <http://www.scielo.br/scielo.php?script=sci arttext\&pid $=$ S1413-70542007000400025 $>$. Accessed: Oct. 03, 2018. doi: $10.1590 / \mathrm{S} 1413-70542007000400025$.

SUNTHONVIT, N. et al. Effects of high-temperature drying on the flavor components in Thai fragrant rice. Drying Technology, v.23, n.7, p.1407-1418, 2005.

TOZIN, L. R. S. et al. Glandular trichome density and essential oil composition in leaves and inflorescences of Lippia origanoides Kunth (Verbenaceae) in the Brazilian Cerrado. Annals of the Brazilian Academy of Sciences, v.87, n.2, p.943-953, 2015. Available from: <http://www.scielo.br/scielo.php?script=sci_ar ttext\&pid=S0001-37652015000200943>. Accessed: Oct. 03, 2018. doi: 10.1590/0001-3765201520140376. 